\title{
Fog Water and Ecosystem Function: Heterogeneity in a California Redwood Forest
}

\author{
Holly A. Ewing, ${ }^{1 *}$ Kathleen C. Weathers, ${ }^{2}$ Pamela H. Templer, ${ }^{3}$ Todd E. \\ Dawson, ${ }^{4}$ Mary K. Firestone, ${ }^{5}$ Amanda M. Elliott, ${ }^{2}$ and Vanessa K. S. \\ Boukili $^{6}$
}

\begin{abstract}
${ }^{1}$ Program in Environmental Studies, Bates College, 111 Bardwell Street, Lewiston, Maine 04240, USA; ${ }^{2}$ Cary Institute of Ecosystem Studies, Box AB, Millbrook, New York 12545, USA; ${ }^{3}$ Department of Biology, Boston University, 5 Cummington Street, Boston, Massachusetts 02215, USA; ${ }^{4}$ Departments of Integrative Biology and Environmental Science, Policy and Management, University of California, Berkeley, Berkeley, California 94720, USA; ${ }^{5}$ Department of Environmental Science, Policy and Management, University of California, Berkeley, Berkeley, California 94720, USA; ${ }^{6}$ Department of Ecology and Evolutionary Biology, University of Connecticut, 75 N. Eagleville Road, Storrs, Connecticut 06269, USA
\end{abstract}

\begin{abstract}
Fog is thought to influence ecological function in coastal forests worldwide, yet few data are available that illuminate the mechanisms underlying this influence. In a California redwood forest we measured water and nitrogen $(\mathrm{N})$ fluxes from horizontally moving fog and vertically delivered rain as well as redwood tree function. The spatial heterogeneity of water and $\mathrm{N}$ fluxes, water availability, tree water use, and canopy $\mathrm{N}$ processing varied greatly across seasons. Water and $\mathrm{N}$ fluxes to soil
\end{abstract}

\footnotetext{
Received 19 August 2008; accepted 12 December 2008; published online 14 February 2009

Author Contributions: We make no distinction in effort and contribution between the first and second authors or between the third and fourth authors. HAE and KCW were responsible for project design, oversight, data analysis, synthesis, and writing. PHT analyzed N samples and contributed significantly to interpretation of data. TED established the initial tree physiology study site, provided and analyzed the data on tree physiology, and contributed to the synthesis of these data. MKF first identified the lack of connection between inputs and microbial processing and catalyzed synthesis regarding belowground processing. AME created figures, performed field and laboratory work, and was database manager. VKSB collected field samples and carried out the litterfall study. All authors edited the paper.
}

*Corresponding author; e-mail: hewing@bates.edu (annual average of $98 \%$ and $89 \%$, respectively) across the whole forest occurred primarily in the rain season and was relatively even across the whole forest. In contrast, below-canopy flux of fog water and $\mathrm{N}$ declined exponentially from the windward edge to the forest interior. Following large fog events, soil moisture was greater at the windward edge than anywhere else in the forest. Physiological activity in redwoods reflected these differences in inputs across seasons: tree physiological responses did not vary spatially in the rain season, but in the fog season, water use was greater, yet water stress was less, in trees at the windward edge of the forest versus the interior. In both seasons, vertical passage through the forest changed the amount of water and form and concentration of $\mathrm{N}$, revealing the role of the tree canopy in processing atmospheric inputs. Although total fog water inputs were comparatively small, they may have important ecosystem functions, including relief of canopy water stress and, where there is fog drip, functional coupling of above- and belowground processes.

Key words: fog; rain; atmospheric deposition; redwood physiology; throughfall; soil moisture; water use; ecosystem $\mathrm{N}$ processing; litterfall. 


\section{INTRODUCTION}

Water is a critical, often limiting, resource that ecologists have long recognized as governing terrestrial ecosystem structure and function (Odum 1971). The amount and timing of water delivery affects species distribution, productivity, and nutrient cycling. Although the spatial and temporal distribution of water is largely climatically controlled, the form in which water reaches terrestrial ecosystems-as rain, snow, fog, rime, or dew-can strongly influence its effect on an ecosystem through variation in timing, distribution, accessibility, and chemistry (Azevedo and Morgan 1974; Weathers and Likens 1997; Dawson 1998; Weathers and others 1986, 2000; Vitousek 2004).

In coastal regions, fog can provide an important fraction of the annual water (Oberlander 1956; Ingraham and Matthews 1990; Dawson 1998) and nutrient deposition necessary for ecosystem function (Azevedo and Morgan 1974; Weathers 1999). Fog formed over adjacent oceans carries with it water, nutrients, and sometimes pollutants, that are of marine as well as terrestrial origin (Weathers and Likens 1997; Weathers and others 2000). In some coastal systems, there are distinct rain and fog seasons, making these environments particularly well suited to explorations of the role that fog plays in ecosystem function (Azevedo and Morgan 1974; Weathers 1999). Most coastal fog travels close to the ground and moves horizontally and is therefore influenced by structural discontinuities in the landscape such as forest or topographic edges in a way that vertically arriving moisture is not. These landscape edges are likely to serve as places of accumulation or depletion of horizontally driven materials, whereas vertical deposition is comparatively more evenly distributed across landscapes (Weathers and others 1992, 1995, 2000). Deposition of fog water, pollutants, and nutrients is therefore spatially heterogeneous and influenced by such variables as wind speed, topographic relief, vegetation structure, canopy architecture, and exposure (Weathers and others 2000). Fog-inundated ecosystems with distinct edges are thus excellent places to examine connections between ecosystem structure (for example, vegetation architecture) and ecological function (for example, primary production and rates of nutrient delivery, cycling, and loss), and those systems with temporal separations in rain and fog deposition make this evaluation especially feasible.
Fog is of particular interest in the coastal forests of California, especially the redwood (Sequoia sempervirens, D.Don) forests where the distribution and timing of water delivery has been hypothesized to be critical in supporting the high and sustained growth of these large trees in the otherwise dry summer months (Azevedo and Morgan 1974; Dawson 1998). Coastal redwoods grow in a band bordering the ocean suggesting that coastal climatic phenomena such as fog may be responsible, at least in part, for their distribution (Noss 2000). For a redwood forest in northern California, Dawson (1998) showed that during the summer fog contributed water not only to the redwoods (19\% of water demand) but also to the forest understory (up to $100 \%$ of water demand during the fog season for some species). Thus the spatial distribution of fog and the nutrients or pollutants it carries are of particular interest in the maintenance of coastal redwood forest ecosystems (Weathers 1999).

In coastal California, redwood forests exist within a mosaic of urban areas, grasslands, agricultural land, and oak forests. Patches of forests that have windward edges bordering grassland or agricultural land are common and likely to display strong biogeochemical gradients that result from horizontally driven materials (Beier and Gundersen 1989; Erisman and others 1997; Weathers and others 2001). We hypothesized here that a gradient in the deposition of water and nitrogen $(\mathrm{N})$ exists from the edge of a redwood forest to the interior during the summer fog season, but not during the winter rain season. Further, we hypothesized that during the fog season these differences in deposition should translate into differences in ecosystem function including plant performance (physiology), soil moisture, and nutrient availability across the forest, and that this spatial pattern is not evident during the rain season.

To test these hypotheses and elucidate further the relative importance of fog in coastal redwood ecosystem function, we measured water and inorganic $\mathrm{N}$ concentrations and flux as well as transpiration, canopy water uptake, water stress, and litterfall in a redwood forest in Sonoma County, California. Our specific objectives were to (1) quantify the spatial and temporal fluxes of water and $\mathrm{N}$ from canopy through surficial soil, (2) determine whether the magnitude and spatial heterogeneity of these fluxes differed for horizontally and vertically delivered materials, and (3) relate these measures of ecosystem inputs and processing to measures of redwood tree water use and forest production. 


\section{MethoDS}

\section{Study Site}

Our research was conducted in an 11 ha remnant old-growth redwood forest at 300 masl elevation, in Sonoma County, California, $\left(38^{\circ} 24^{\prime} \mathrm{N}, 122^{\circ}\right.$ $59^{\prime} \mathrm{W}$ ) approximately $8 \mathrm{~km}$ from the ocean (Burgess and Dawson 2004). The forest is located on a ridge with loamy soils with no metropolitan areas and one primary road (Rte 1) between the ocean and the forest. The forest is surrounded by grassland, agricultural land (vineyards), deciduous forest, second-growth redwood forests, and interspersed residential development. The trees on the western (ocean-facing) side of the study forest have limbs that extend to the ground on their windward side suggesting that these $400+$ year-old trees have always been at a forest edge (Roden and others, unpublished). The climate is Mediterranean with hot dry summers (mean annual July temperature, $19.6^{\circ} \mathrm{C}$ for $1971-2000$, National Weather Service, Santa Rosa, CA, $20 \mathrm{~km}$ northwest of the site) and rainy, mild winters (mean annual January temperature, $8.9^{\circ} \mathrm{C}$ ). Although the region receives $78 \mathrm{~cm}$ of precipitation annually (National Weather Service, Santa Rosa mean 1971-2000), more than $97 \%$ of it typically falls between October and May (hereafter rain season). Although the total amount of rainfall at the study site was greater than at Santa
Rosa, the partitioning between rain and no rain months was the same; the warm summer growing season (hereafter fog season) is a time of little rain.

\section{Field Sampling}

A total of 44 throughfall (TF) collectors-funnels situated on PVC posts approximately $90 \mathrm{~cm}$ above the ground and attached via tubing to bottles to collect water falling through the canopy-were distributed throughout the forest in a stratified random design following Weathers and others (1995, 2001) (Figure 1). Eight collectors were placed randomly within each of five approximately $60 \mathrm{~m}$-wide bands that stretched across the forest patch perpendicular to the prevailing westerly winds. Four additional collectors were placed randomly within the first $30 \mathrm{~m}$ of the windward (western) edge. Leaf area index (LAI) was quantified using two LAI-2000 Plant Canopy Analyzers (LiCor Biosciences, USA), one immediately above each TF collector which was calibrated against a reference analyzer outside the forest (Gower and others 1999). We sampled all 44 TF collectors in the fog season, but in the rain season, we sampled TF from two randomly selected collectors per band to characterize each band. Two additional open (bulk) collectors were placed outside the forest southwest of the forest stand, and these were sampled year-

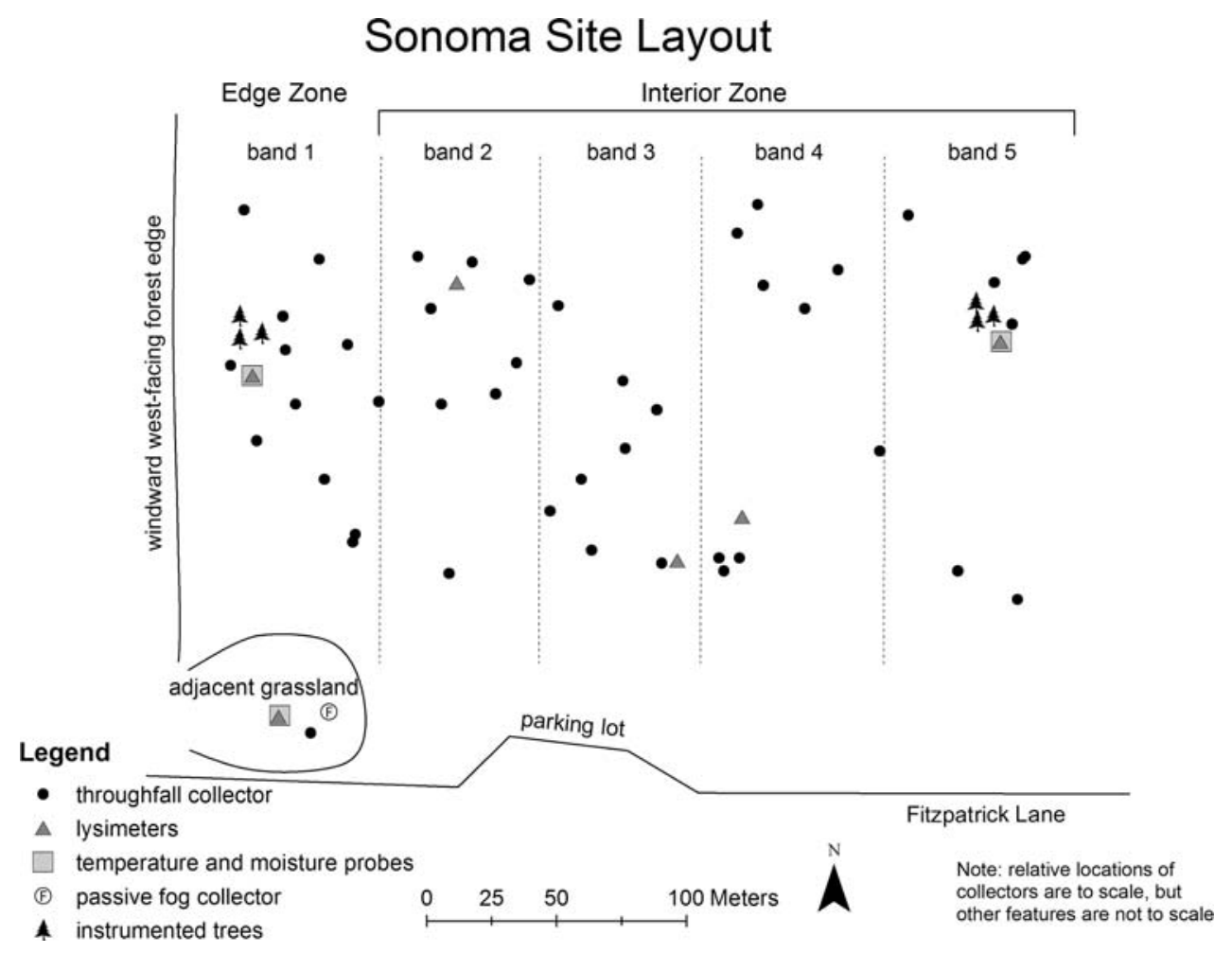

Figure 1. Sampling locations of instrumented trees (tree symbol ), throughfall collectors $(\mathbf{)})$, soil moisture and temperature probes (squares $\mathbf{\square}$ ), zero-tension and tension lysimeters (triangles $\mathbf{\Delta}$ ), and fog collector $(\mathrm{F})$, redwood forest in Sonoma County, CA. 
round. Fog water was collected outside the forest using a passive fog collector with a plastic mesh collection surface (after Azevedo and Morgan 1974).

Liquid samples from fog, bulk, and throughfall collectors were removed every week in the fog season (June to October, 2003-2005) and every two weeks in the rain season (approximately November through May 2003-2006). Limited collections were made during the rain season of 20032004. For each sampling period, water was combined in the field by band for later chemical analysis. In the rain season when water volumes were large, collections were volume-weighted. Samples were filtered (glass A/E filter) within a day of collection and refrigerated at $4{ }^{\circ} \mathrm{C}$ or frozen until analysis.

Soil water was collected using tension (TL) and zero-tension lysimeters (ZTL). Two TL (Soil Moisture 1900 series) were placed at $12 \mathrm{~cm}$ depth approximately $2 \mathrm{~m}$ apart in each of the five forest bands (Figure 1). Tension was set at $50 \mathrm{kPa}$ after each sampling. Near these TL within each of the five bands and near bulk collectors, a soil pit was dug and two ZTL were installed into the undisturbed pit wall at $70 \mathrm{~cm}$ depth to collect water draining through the overlying soil. Zero-tension lysimeters consisted of a PVC trough $9.84 \mathrm{~cm}$ in diameter and $25.24 \mathrm{~cm}$ long (cut at an angle to taper) installed approximately $20^{\circ}$ from horizontal. Soil pits were backfilled after installation of ZTL and temperature and moisture probes (described below).

In three of the soil pit locations-the forest edge, forest interior, and outside the forest-continuous soil temperature and moisture data also were collected (Figure 1). Volumetric water content was measured using time-domain reflectometry (TDR) with Campbell Scientific water content reflectometers (CS616-L) installed at an angle from $1-10 \mathrm{~cm}$ and horizontally at 35 and $70 \mathrm{~cm}$. Volumetric soil moisture values were generated from the TDR reflection patterns following Campbell Scientific's protocol, based on the general equation of Rhoades and others (1976, 1989). Type $\mathrm{T}$ thermocouples (copper-constantan) were used for temperature readings at $3,10,35$, and $70 \mathrm{~cm}$ within the same soil pit.

Liquid in TL and ZTL was collected at the same time fog, bulk, and TF collections were made, filtered as above, and refrigerated at $4^{\circ} \mathrm{C}$ or frozen until analysis. Samples in the two TL within each band were combined. Collections from each pair of ZTL were also combined, but because these collections were often large, only a total of $500 \mathrm{ml}$, volume-weighted based on the collections in the two lysimeters, was kept.

Measures made on redwood trees included leaf wetness, xylem pressure potential, sapflow velocity, and the carbon isotope ratio $\left(\delta^{13} \mathrm{C}\right)$ of new leaves in the upper, sun-lit, canopy (54-63 m above the ground), as well as litterfall to the forest floor. Leaf wetness and sapflow sensor deployment and data reduction follow the methods of Burgess and Dawson (2004) but are briefly described here. The sensors were deployed from 2001 to 2004 in the canopies of six trees, three at the western edge of the forest and another three approximately $300 \mathrm{~m}$ east of that edge in the forest interior near the datalogger and lysimeter cluster located furthest east in the forest patch (Figure 1). Leaf wetness was determined using resistance-based sensors (Campbell Scientific model 237-L, Logan UT) placed at two heights within the live crowns of each tree. Additionally, measurements of both transpiration (flow from soil to atmosphere) and foliar uptake by crown leaves (reverse flow) was determined using the heat-ratio sapflow method. Continuous data from 2003 and 2004 were used here. Xylem pressure potential was measured at mid-day (12:30-14:00) approximately every 1218 days between mid-April and the end of October (fog season) and every 21 days during the rain season (November to early April) using a standard pressure chamber (model 1000, PMS Instruments, Corvallis, OR) following Burgess and Dawson (2004). Methods for collection and analysis of leaf samples for $\mathrm{C}$ isotopic composition are described in Burgess and Dawson (2007). Here we use only data from new leaves produced in 2003 and 2004 in the upper $2 \mathrm{~m}$ of the tree crowns (trees range from 58 to $67 \mathrm{~m}$ tall). Litterfall was collected in $240.27 \mathrm{~m}^{2}$ screened baskets spread in a stratified random pattern to cover the entire forest. Collections were made monthly from January 2005 to January 2007, dried, and sorted as leaves, wood/bark, reproductive structures, lichen, or non-plant materials.

\section{Chemical Analyses}

Rain, fog water, TF, and soil solution samples were analyzed for $\mathrm{N}$ as $\mathrm{NO}_{2}{ }^{-}+\mathrm{NO}_{3}{ }^{-}$(hereafter $\mathrm{NO}_{3}^{-}-\mathrm{N}$ ) and $\mathrm{NH}_{4}^{+}$(hereafter $\mathrm{NH}_{4}^{+}-\mathrm{N}$ ) on a Lachat QC 8000 flow-injection analyzer, using identical methods, at either the Cary Institute of Ecosystem Studies (IES), Millbrook, New York, or the University of California, Berkeley (UCB). The method detection limit was $0.0045 \mathrm{mg} / \mathrm{l}$ for $\mathrm{NO}_{3}^{-}-\mathrm{N}$ and $0.0156 \mathrm{mg} / \mathrm{l}$ for $\mathrm{NH}_{4}^{+}-\mathrm{N}$ at IES and $0.01 \mathrm{mg} \mathrm{N} / \mathrm{l}$ for 
both $\mathrm{NO}_{3}^{-}-\mathrm{N}$ and $\mathrm{NH}_{4}^{+}-\mathrm{N}$ at UCB. Samples with concentrations below this were set at half the detection limit for data handling. Foliage $\delta^{13} \mathrm{C}$ was determined on a PDZ Europa Scientific 20/20 mass spectrometer at the University of California Center for Stable Isotope Biogeochemistry.

\section{Calculations and Statistical Analyses}

\section{Atmospheric Deposition}

(1) Atmospheric deposition via rain was measured as the product of rain concentration and volume in open (bulk) collectors placed outside the forest stand. Bulk deposition collectors measure rain water as well as some dry particles (Lovett 1994); we considered these data a measure of water and $\mathrm{N}$ deposition via vertical transport outside the forest. (2) We calculated fog deposition as the product of fog water concentration measured using the passive fog collector outside the forest and TF volume collected in the forest during the summer fog season. This calculation is one of the most direct measurements of actual fog deposition to a forest canopy, but is an underestimate because of water evaporation from the canopy (Weathers and others 1995). Direct measures of fog deposition, and dry deposition, to heterogeneous canopies were not logistically or methodologically feasible (Lovett 1994; Weathers and others 1992, 1995).

\section{Throughfall (TF)}

Calculation of TF water and $\mathrm{N}$ flux to the forest floor was made by collector and by band. Water flux was calculated as the total volume of water collected per area of funnel. Nitrogen flux was calculated by multiplying the concentration of $\mathrm{NH}_{4}^{+}-\mathrm{N}$ or $\mathrm{NO}_{3}^{-}-\mathrm{N}$ in samples bulked within a band by the total water flux for that band within each sampling period. Annual $\mathrm{N}$ and water flux were calculated by summing flux within a sampling period across all sampling periods in the year. In 2003 when the full fog and rain seasons were not sampled, the flux for the unmeasured portion of the season was assumed to have occurred at the same rate as within the measured portion of the season. All measurable TF in the rain season is considered rain, and in the summer fog season TF in excess of bulk collections (net throughfall, NTF, below) is assumed to be fog drip. We assume that water collected outside the forest in bulk collectors during the summer fog season was primarily from small $(<2 \mathrm{~mm})$ precipitation events that occur occasionally within the fog season (Santa Rosa data).

\section{Net Throughfall Flux (NTF)}

We calculated NTF for both the fog and rain seasons to contrast water and $\mathrm{N}$ fluxes to the forest floor between the two seasons and relative to outside the forest stand.

$$
\mathrm{NTF}=\mathrm{TF}-\mathrm{B}_{\mathrm{d}}
$$

where TF $=$ water $(\mathrm{cm})$ or nutrient flux $(\mathrm{kg} \mathrm{N} / \mathrm{ha} /$ unit time) from below canopy to forest floor, and $\mathrm{B}_{\mathrm{d}}=$ bulk deposition ( $\mathrm{cm}$ water or $\mathrm{kg} \mathrm{N}$ collected in bulk collectors/ha/unit time).

\section{Water and N Leaching from Surficial Soil}

An approximation of water and $\mathrm{N}$ leaching from the upper $70 \mathrm{~cm}$ was made from ZTL collections. Although collection efficiencies of ZTL are usually low and variable and so necessitate use of a water balance model for calculation of flux (Lajtha and others 1999), the extremely wet conditions of the rain season and frequent saturation of soil to $70 \mathrm{~cm}$ led to consistently large collections in all ZTL. We used the areal collection surface of lysimeters and volumes of collections to calculate rough estimates of water and $\mathrm{N}$ leaching from the top $70 \mathrm{~cm}$ of the profile:

$\mathrm{cm}$ water flux $=\mathrm{cm}^{3}$ of water per collection ${ }^{*}\left(227.5 \mathrm{~cm}^{2} \text { areal exposure }\right)^{-1 *}$ (collection period $)^{-1}$.

Seasonal $\mathrm{N}$ leaching from the top $70 \mathrm{~cm}$ of soil was approximated by summing across all ZTL collections the product of the sample $\mathrm{N}$ concentration and water flux for that collection period.

\section{Spatial and Temporal Averaging}

Data for TF are presented as average flux to each collector by season, as well as for zones within the forest: the "edge" includes data averaged for the region from the canopy drip line $(0 \mathrm{~m})$ to $60 \mathrm{~m}$ into the forest and summed across collection periods. Similar fluxes were calculated for the "interior" zone across bands 2-5 (61-309 $\mathrm{m}$ into the forest; Figure 1). For the "entire forest" calculations, the flux for each band was calculated before averaging across all bands, and the seasonal flux is the summation of the average flux to the whole forest in each sampling period. We use the term deposition when referring to atmospheric deposition of water or nutrient to forest or open area per unit area per unit time. We use flux to mean the delivery of water or $\mathrm{N}$ to the forest floor or soil after it has been deposited to the canopy, also per unit area per unit time. Time intervals vary depending on the analysis. 


\section{Plant Physiological Function}

Measurements of redwood tree function were grouped according to location in the forest. For leaf wetness, sapflow velocity, xylem pressure potential, and leaf carbon isotope composition, data were split into rain and fog seasons for edge and interior trees. Leaves were scored as "wet" when leaf wetness sensor resistance fell below $100 \mathrm{kOhms}$ for at least $2 \mathrm{~h}$. Transpiration is expressed here as a normalized value relative to the maximum value measured for the trees at each location. Reverse sapflow, or foliar/crown water uptake, was determined when velocities in the reverse direction exceeded $1 \mathrm{~cm} / \mathrm{h}$ for a minimum of 2 full hours. This cut-off was then used for determining the number of days on which a tree exhibited canopy uptake (as discussed in Burgess and Dawson 2004). Litterfall for each basket across the 2-year collection period was summed and regressed against the distance of the basket from the western, windward edge of the forest.

For all data, final determination of the distinction between seasons was made after field data were collected based on the onset and termination of $2 \mathrm{~mm}$ rain events at the Santa Rosa National Weather Service station. Linear and non-linear regression analyses and data handling were performed in SAS (v. 9.1, SAS corporation) and JMP (v. 6.0, SAS corporation).

\section{Results}

\section{Throughfall and Bulk Water Collections}

Throughfall (TF) water-water that has dripped from the canopy to the forest soil-showed different spatial patterns in fog and rain seasons. Water fluxes during the rain season were relatively evenly distributed throughout the forest (Figure 2A); there was no trend with distance from the edge $\left(R^{2}=0.0017, P>0.05\right)$ although, on average, the edge zone received more water than the interior (Table 1). Fog water TF fluxes to the forest, however, showed a pronounced edge effect during the summer fog season: they decreased exponentially $\left(\mathrm{y}=\theta_{1} \mathrm{e}^{\wedge}\left(\theta_{2} \mathrm{x}\right)+\theta_{3}\right.$, where $\theta_{1}=117.84(16.42)$, $\theta_{2}=0.0309 \quad(0.0073)$, and $\theta_{3}=8.409 \quad(4.01)$ (approximate standard errors in parentheses), $\left.R^{2}=0.66\right)$ from edge to interior and averaged 6.6fold higher in the edge zone $(0-60 \mathrm{~m})$ compared to the interior of the forest (61-309 $\mathrm{m}$ from the edge) (Table 1, Figures 1 and 2).

Water flux to the forest floor of the entire forest stand over the 3-year collection period was on

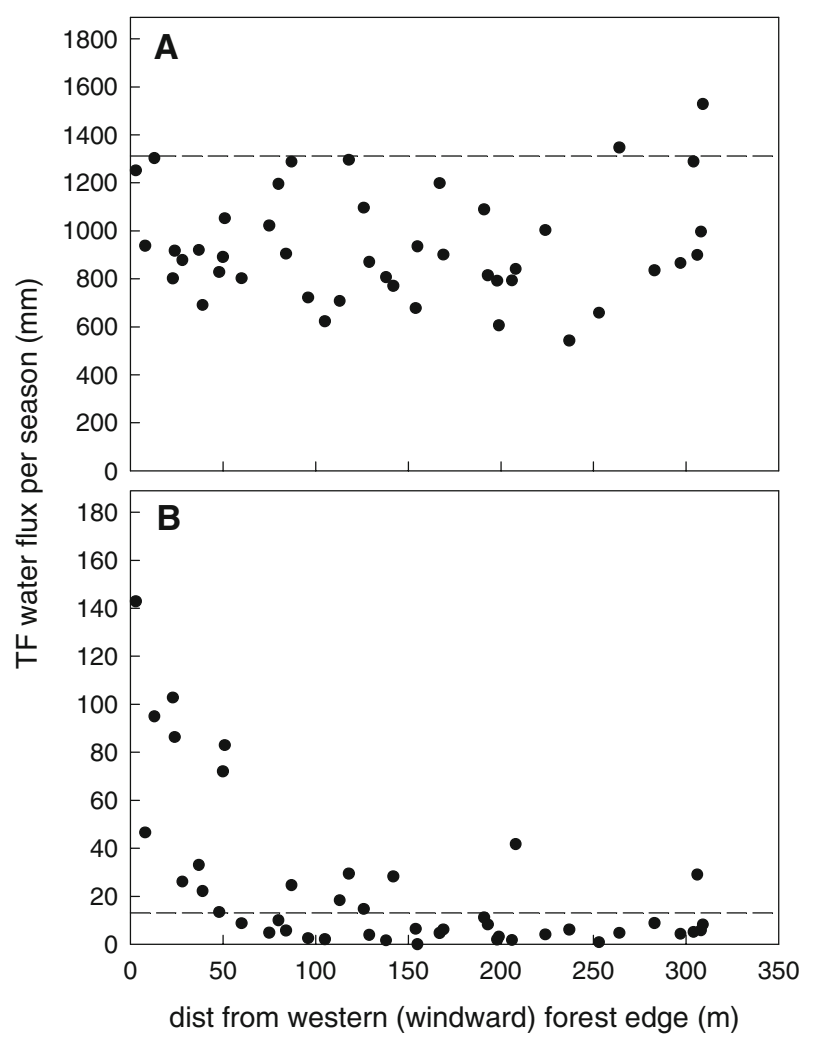

Figure 2. Total water flux for the season in mm (average $\mathrm{mm} /$ collector/season) for $(\mathbf{A})$ rain and $(\mathbf{B})$ fog seasons in a Sonoma County, CA redwood forest. Values are averages across all years of the study. For the fog season, there is an exponential decrease in throughfall water flux with distance from the forest edge (see text for equation, $\left.R^{2}=0.66\right)$. Dashed lines show the amount of water that accumulated in an open (bulk) collector outside the forest.

average 58 -fold higher in the rain compared to fog season with rain accounting for $98 \%$ of total standlevel TF water accumulation (Table 1). Forest structure as measured by LAI above each TF collector did not explain a significant amount of the variance in throughfall during either fog or rain seasons $\left(R^{2}=0.003, P>0.05\right.$ for fog season and $R^{2}=0.074, P>0.05$ for rain season).

Average net throughfall (NTF, equation(1)) showed water loss, presumably via either canopy evaporation or uptake of approximately $18 \%$ during the rain season (TF $<$ bulk deposition, Figure 2A), as well as fog water flux primarily at the forest edge during the fog season (TF $>$ bulk deposition, Figure 2B). Thus, soils in the adjacent open grassland received more vertically deposited rain water during the winter than did soils under the forest canopy, but they received virtually no horizontally deposited fog water. 
Table 1. Water Inputs in Bulk Precipitation (Outside the Forest), in Throughfall (TF), and in Zero-Tension Lysimeters (ZTL) as well as Water Volumes for Tension Lysimeters (TL) During Fog and Rain Seasons, Redwood Forest Stand, Sonoma County, CA

\begin{tabular}{|c|c|c|c|c|c|c|c|c|}
\hline & $\begin{array}{l}\text { Fog } \\
\text { season } \\
2003\end{array}$ & $\begin{array}{l}\text { Fog } \\
\text { season } \\
2004\end{array}$ & $\begin{array}{l}\text { Fog } \\
\text { season } \\
2005\end{array}$ & $\begin{array}{l}\text { Mean } \\
\text { fog } \\
\text { season }\end{array}$ & $\begin{array}{l}\text { Rain } \\
\text { season } \\
\text { 2003-2004 }\end{array}$ & $\begin{array}{l}\text { Rain } \\
\text { season } \\
2004-2005\end{array}$ & $\begin{array}{l}\text { Rain } \\
\text { season } \\
\text { 2005-2006 }\end{array}$ & $\begin{array}{l}\text { Mean } \\
\text { rain } \\
\text { season }\end{array}$ \\
\hline \multicolumn{9}{|c|}{ Water flux (mm/season) } \\
\hline Bulk precipitation & 13.70 & 14.28 & 10.57 & 12.85 & 1087.89 & 1254.92 & 1729.19 & 1357.33 \\
\hline TF forest edge & 64.14 & 60.11 & 49.42 & 57.89 & 600.10 & 1197.25 & 1748.87 & 1182.07 \\
\hline TF forest interior & 7.58 & 9.94 & 8.82 & 8.78 & 589.02 & 1089.97 & 1584.40 & 1087.80 \\
\hline TF entire forest & 18.89 & 19.98 & 16.94 & 18.60 & 591.23 & 1111.42 & 1617.30 & 1106.65 \\
\hline ZTL clearing & 0.00 & 0.00 & 0.04 & 0.01 & 363.94 & 1294.05 & 1144.46 & 934.15 \\
\hline ZTL forest edge & 0.01 & 0.00 & 0.16 & 0.06 & 308.38 & 535.05 & 940.51 & 594.65 \\
\hline ZTL forest interior & 0.02 & 21.84 & 0.15 & 7.34 & 352.10 & 1208.67 & 1070.20 & 876.99 \\
\hline ZTL entire forest & 0.02 & 17.47 & 0.15 & 5.88 & 343.36 & 1073.94 & 1044.26 & 820.52 \\
\hline \multicolumn{9}{|c|}{ Water volume (L/season) } \\
\hline TL forest edge & 2.00 & 5.17 & 5.38 & 4.18 & 4.69 & 18.42 & 13.90 & 12.33 \\
\hline TL forest interior & 0.00 & 1.64 & 1.92 & 1.19 & 5.13 & 18.15 & 12.82 & 12.03 \\
\hline TL entire forest & 0.50 & 2.52 & 2.79 & 1.94 & 5.02 & 18.22 & 13.09 & 12.11 \\
\hline
\end{tabular}

Collection locations include outside the forest (bulk) and TF in the forest edge zone (0-60 $\mathrm{m}$ from windward forest edge), the forest interior (61-309 $\mathrm{m}$ ), and averaged for the forest stand (entire forest) (Figure 1).

\section{Soil Moisture and Temperature}

Soil water accumulated in lysimeters primarily during the rain season. No water was collected from the ZTL (70 $\mathrm{cm}$ deep) in any of the bands after the first month of the fog season. With the onset of rains, ZTL began collecting water after approximately $10 \mathrm{~cm}$ of water via TF flux reached the forest floor, and they continued to collect detectable amounts of water through the beginning of the fog season (May). Averaged across all years, ZTL in the clearing and forest interior collected 1.6 and 1.5 times more water, respectively, than ZTL in the edge zone (Table 1). The 3-year average soil water collection for the forest stand was slightly lower than for the clearing adjacent to the forest (Table 1).

Tension lysimeters (12 cm deep) began collecting water as soon as the rain season began, and they collected until approximately 2-4 weeks into the fog season. After the first month of the fog season, only TL at the western, windward edge of the forest (Figure 1) collected water following large fog events; TL collections were coincident with fog drip that accumulated in TF collectors. On average across all years, total accumulation in TL, a measure of water held at less than $50 \mathrm{kPa}$ of pressure $(-50 \mathrm{kPa}$ or $-0.05 \mathrm{MPa}$ soil moisture potential), was 6 -fold greater in the rain season than the fog season, and 3.5-fold greater at the edge than the interior during the fog season (Table 1).
The patterns in soil moisture recorded by TDR probes were similar to those observed with lysimeters, but temporal patterns and differences among soil depths could be seen with greater resolution. Soil moisture as measured by TDR was similar across all sampling locations in the rain season when all sites and all depths were wet and surficial soil became wetter after rainfall events (Figure 3). In the fog season, surficial soil dried at all sites, and there was greater soil moisture at 70 than $35 \mathrm{~cm}$. However, after fog events, the probe at $0-10 \mathrm{~cm}$ on the western edge of the forest recorded large increases in soil moisture as TF from fog events wet the soil (Figure 3). At $35 \mathrm{~cm}$ depth, a small increase in volumetric soil moisture was also sometimes associated with large fog events, but no changes in moisture occurred at $70 \mathrm{~cm}$. None of the probes at any depth in either the interior of the forest or the open field registered increased moisture after fog events, and surficial soil in these locations dried throughout the summer.

Soil temperatures were more variable spatially and temporally during the fog season than the rain season (data not shown). Soil temperatures were generally higher in the clearing compared to the forest edge. Furthermore, the forest interior had, on average, slightly warmer soil temperatures than the edge. Average fog season $10-\mathrm{cm}$ depth soil temperatures were $17^{\circ} \mathrm{C}$ (range $13-20^{\circ} \mathrm{C}$ ) in the clearing, $14.5^{\circ} \mathrm{C}$ (range $12-17^{\circ} \mathrm{C}$ ) at the edge, and 


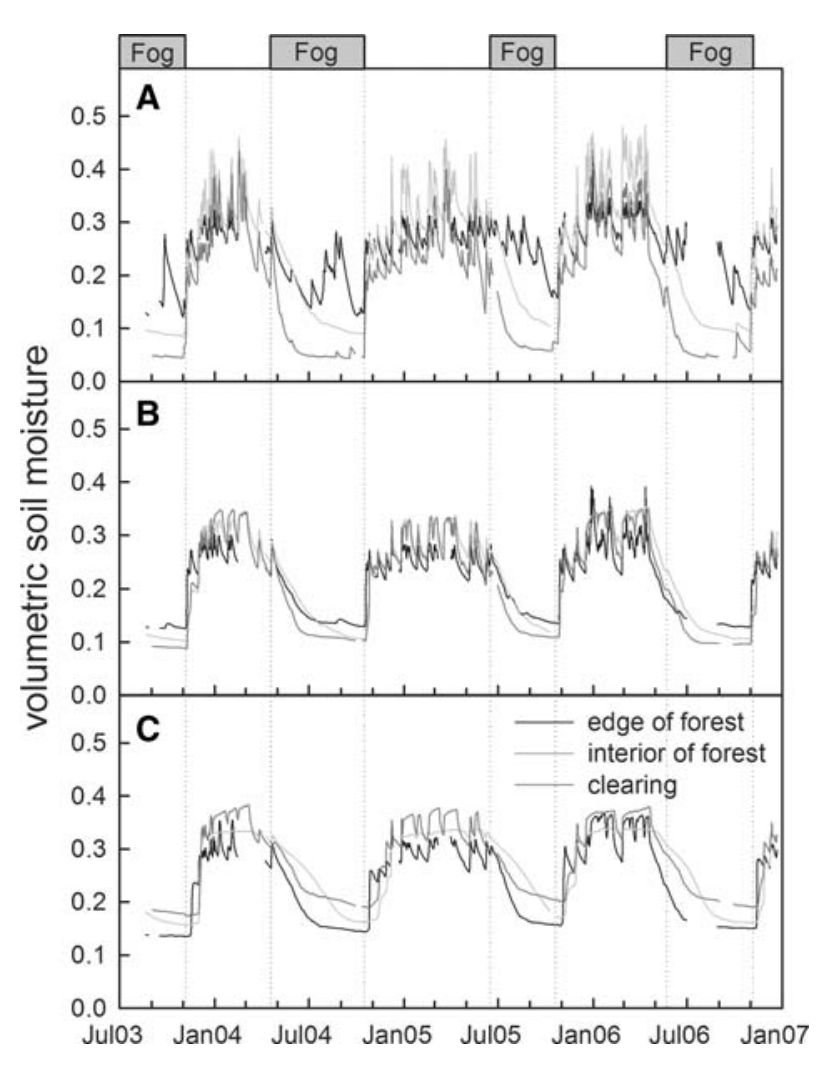

Figure 3. Volumetric soil moisture (as measured by TDR probes) by location within a redwood forest stand in Sonoma County, CA (open, edge zone, interior zone, see Figure 1) and soil depth (A) 0-10 cm, (B) $35 \mathrm{~cm},(\mathbf{C})$ $70 \mathrm{~cm}$ from August 2003 to December, 2006.

$15^{\circ} \mathrm{C}$ (range $13-18^{\circ} \mathrm{C}$ ) in the interior. Average rain season $10-\mathrm{cm}$ depth soil temperatures were $4-7^{\circ} \mathrm{C}$ cooler at the same locations (clearing, edge interior) compared to the fog season. Average $35-\mathrm{cm}$ soil depth temperatures were cooler in the fog season and warmer in the rain season than at $10 \mathrm{~cm}$ depth. Soil temperature was most variable at the surface, which was warmer in the fog season and cooler in the rain season than soil at $70 \mathrm{~cm}$ depth.

\section{Nitrogen Fluxes in Fog, Rain, Throughfall, and Soil Water}

\section{Outside the Forest}

Fog water in 2004 was an average of 35 and 15 times more concentrated in $\mathrm{NO}_{3}^{-}-\mathrm{N}$ and $\mathrm{NH}_{4}^{+}-\mathrm{N}$, respectively, than bulk samples collected during the rain season (Table 2). The very small volume of bulk precipitation that was collected during the fog season was also more concentrated than that collected in the rain season (Table 2). When combined with water deposition amounts during the rain season, and TF water during the fog season, these concentrations translate into deposition of $0.78 \mathrm{~kg} \mathrm{~N} / \mathrm{ha}$ to the forest canopy and $0.23 \mathrm{~kg} \mathrm{~N} / \mathrm{ha}$ in the open during the fog season, both somewhat less than the $1.65 \mathrm{~kg} \mathrm{~N} / \mathrm{ha} / \mathrm{y}$ delivered on average in the rain season (Table 3, see "Methods" section).

Average concentrations of dissolved inorganic N (DIN) in rain (bulk) and fog collected outside the forest were highly variable among events (data not shown). Average fog water concentrations of $\mathrm{NO}_{3}^{-}-$ $\mathrm{N}$ were 4.5 -fold higher than $\mathrm{NH}_{4}^{+}-\mathrm{N}$ (Table 2). Likewise, bulk rain water $\mathrm{NO}_{3}^{-}-\mathrm{N}$ concentrations were 2 -fold higher than $\mathrm{NH}_{4}^{+}-\mathrm{N}$, a pattern evident in bulk collections made during the fog season as well (Table 2).

\section{Inside the Forest-Throughfall $N$ Concentrations}

Average $\mathrm{N}$ concentrations in TF water for the entire forest stand were more variable in the fog season than in the rain season, and were, on average, several-fold higher in fog- than in rain-throughfall (Table 2). Throughfall from both fog and rain seasons was on average across the forest 1.78 times as concentrated in $\mathrm{NO}_{3}^{-}-\mathrm{N}$ as $\mathrm{NH}_{4}^{+}-\mathrm{N}$, but this difference was much greater at the edge where the $\mathrm{NO}_{3}^{-}-$ $\mathrm{N}: \mathrm{NH}_{4}^{+}-\mathrm{N}$ ratio was 3.78 (Table 2 ). Throughfall from the rain season was also more concentrated in $\mathrm{NO}_{3}^{-}-\mathrm{N}$ and $\mathrm{NH}_{4}^{+}-\mathrm{N}$ than bulk rain collected outside the forest (Table 2). During the fog season, TF had higher $\mathrm{NH}_{4}^{+}-\mathrm{N}$ concentrations, but lower or comparable $\mathrm{NO}_{3}^{-}-\mathrm{N}$ than bulk samples collected outside the forest (Table 2).

\section{Throughfall N Flux}

Dissolved inorganic nitrogen TF flux was greater during the rain season than during the fog season (Figure 4A and B). Across the entire forest stand, $89 \%$ of the annual total DIN was delivered to the forest floor during the rain season and $11 \%$ during the fog season. At the forest edge, $79 \%$ of the DIN was deposited to the forest floor during the rain season and $21 \%$ in the fog season. Below-canopy DIN flux at the western, windward forest edge was seven times greater than to the interior zone during the fog season but only 1.4 times greater during the rain season (Figure 4, Table 3 ).

In general, most DIN was delivered to the forest floor as $\mathrm{NO}_{3}^{-}-\mathrm{N}$ (Figure $4 \mathrm{~A}$ and $\mathrm{B}$ ). At the forest edge, $\mathrm{NH}_{4}^{+}-\mathrm{N}$ was consistently about $20 \%$ of total DIN flux, regardless of season, but a larger proportion of the DIN was deposited as $\mathrm{NH}_{4}^{+}-\mathrm{N}$ in the forest interior $(57 \%$ in fog season and $38 \%$ in rain season) (Figure $4 \mathrm{~A}$ and $\mathrm{B}$ ). Nitrogen in $\mathrm{NH}_{4}^{+}$makes up about one-third of DIN flux to the forest as a whole regardless of season (Figure $4 \mathrm{~A}$ and $\mathrm{B}$ ). 


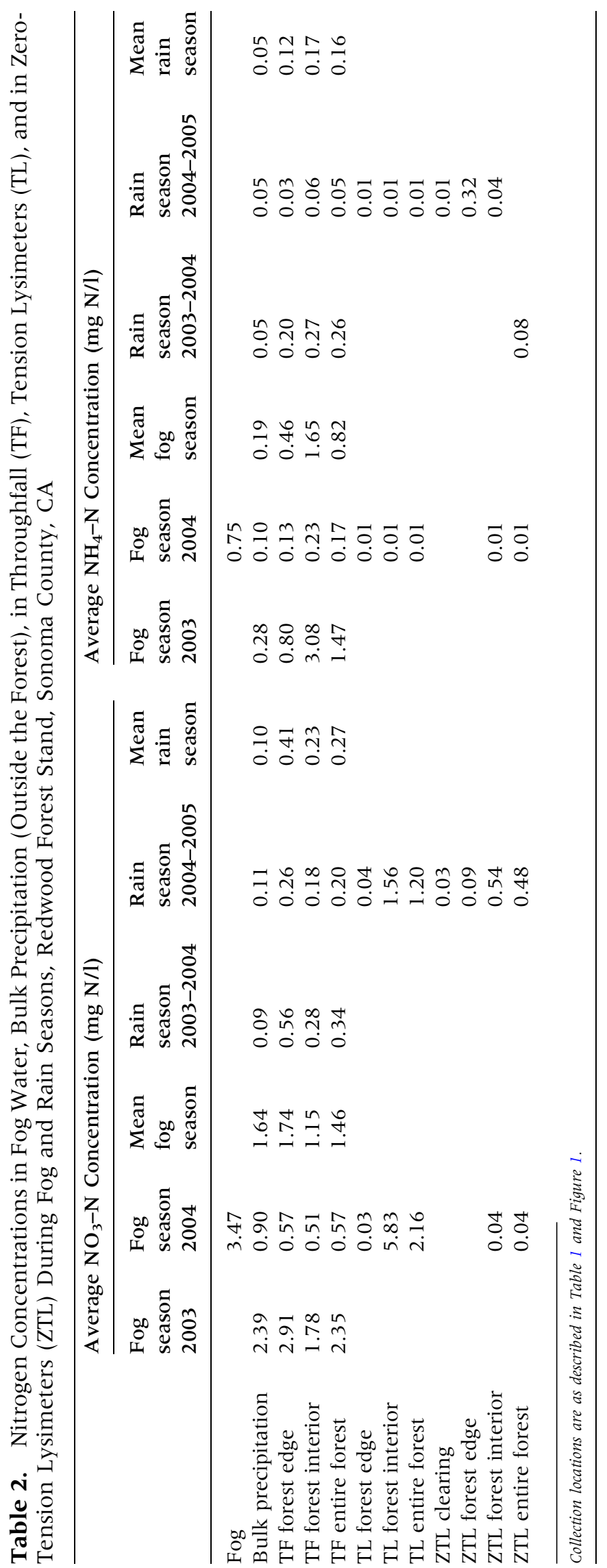


Table 3. Dissolved Inorganic N (DIN) Flux Calculated for Fog (Fog Chemistry*TF Water, see Text), Bulk Precipitation (Collected Outside the Forest), in Throughfall (TF), and in Zero-Tension Lysimeters (ZTL) During Fog and Rain Seasons, Redwood Forest Stand, Sonoma County, CA

\begin{tabular}{|c|c|c|c|c|c|c|}
\hline & \multicolumn{6}{|c|}{ Average dissolved inorganic nitrogen flux (kg N/ha/season) } \\
\hline & $\begin{array}{l}\text { Fog } \\
\text { season } \\
2003\end{array}$ & $\begin{array}{l}\text { Fog } \\
\text { season } \\
2004\end{array}$ & $\begin{array}{l}\text { Mean } \\
\text { fog } \\
\text { season }\end{array}$ & $\begin{array}{l}\text { Rain } \\
\text { season } \\
\text { 2003-2004 }\end{array}$ & $\begin{array}{l}\text { Rain } \\
\text { season } \\
\text { 2004-2005 }\end{array}$ & $\begin{array}{l}\text { Mean } \\
\text { rain } \\
\text { season }\end{array}$ \\
\hline Atmospheric deposition to canopy & & & 0.78 & & & 1.62 \\
\hline Bulk precipitation & 0.37 & 0.10 & 0.23 & 1.48 & 1.75 & 1.62 \\
\hline TF forest edge & 1.73 & 0.36 & 1.05 & 4.57 & 3.33 & 3.95 \\
\hline TF forest interior & 0.24 & 0.06 & 0.15 & 3.27 & 2.45 & 2.86 \\
\hline TF entire forest & 0.63 & 0.12 & 0.37 & 3.53 & 2.63 & 3.08 \\
\hline ZTL clearing & & 0.00 & & & 0.47 & \\
\hline ZTL forest edge & & 0.00 & & & 1.69 & \\
\hline ZTL forest interior & & 0.03 & & & 7.27 & \\
\hline ZTL entire forest & & 0.02 & & & 6.20 & \\
\hline
\end{tabular}

Collection locations are as described in Table 1 and Figure 1.
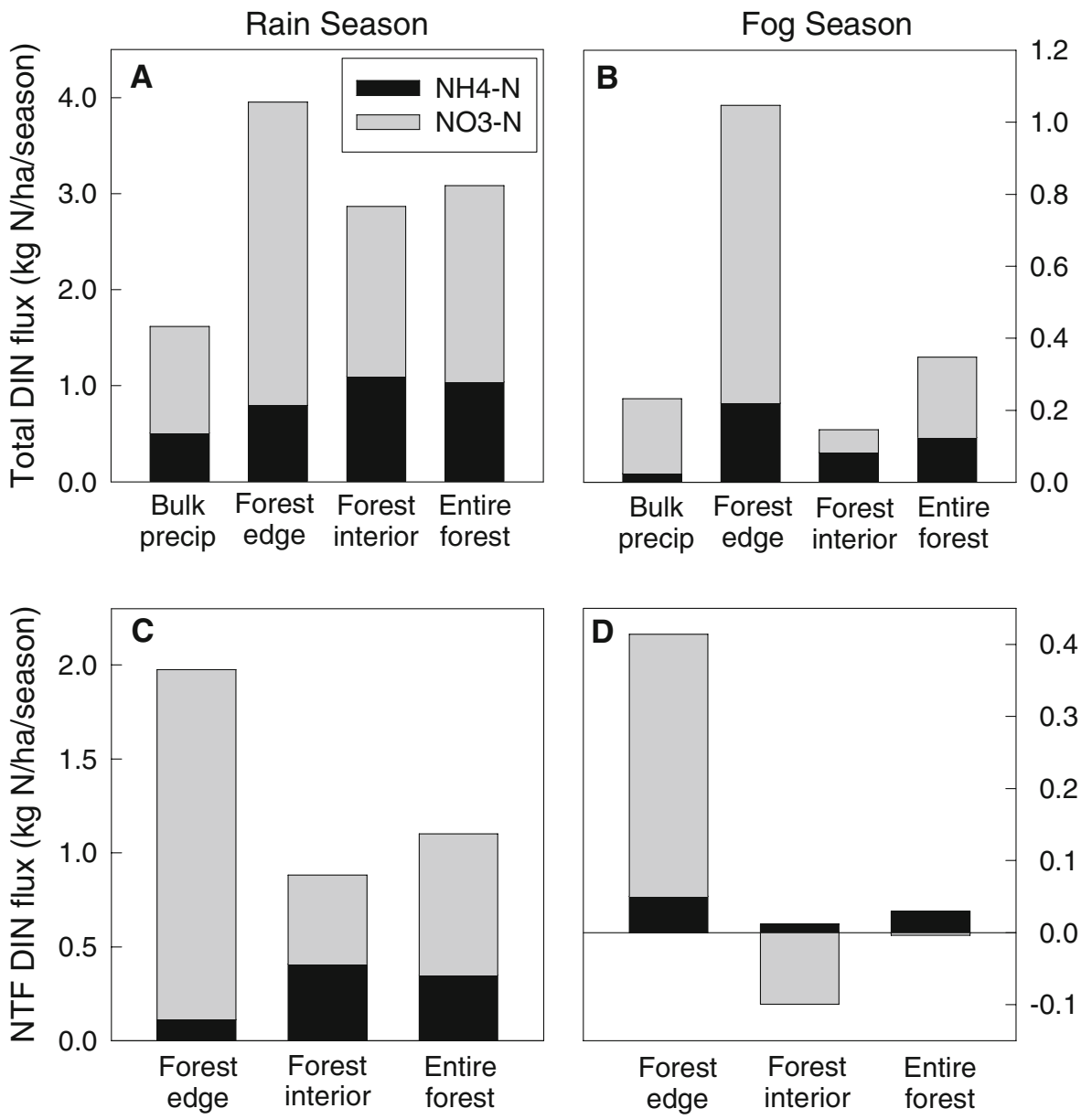

Figure 4. Variation in $\mathrm{N}$ input across the study site $(\mathbf{A}, \mathbf{B})$ and between forest and bulk collectors outside the forest $(\mathbf{C}$, D). Average dissolved inorganic nitrogen flux (kg N/ha/season) during the $(\mathbf{A})$ rain season and (B) fog season. Average net throughfall (NTF, the difference between collections inside the forest and outside) by $\mathrm{N}$ species, $\mathrm{NH} 4{ }^{+}-\mathrm{N}$ and $\mathrm{NO}_{3}^{-}-\mathrm{N}$ during the (C) rain season and (D) fog season. Data are presented for precipitation collected outside the forest (bulk), and throughfall in the forest edge zone $(0-60 \mathrm{~m}$ from windward edge), the forest interior (61-309 m), and for the average of the forest stand (entire forest). Note the differences in the $y$-axis scales between rain $(\mathbf{A}, \mathbf{C})$ and fog $(\mathbf{B}$, D) seasons.
Net throughfall of DIN averaged for the entire forest was positive (TF $>$ bulk) in both rain and fog seasons (Figure 4C and D). Net DIN flux in the edge zone was greater than the interior; in fact, in the fog season there was negative NTF (net uptake) in the interior zone. In both rain and fog seasons $\mathrm{NTF}$ of $\mathrm{NO}_{3}^{-}-\mathrm{N}$ was greatest at the edge (Figure 4C and D). 

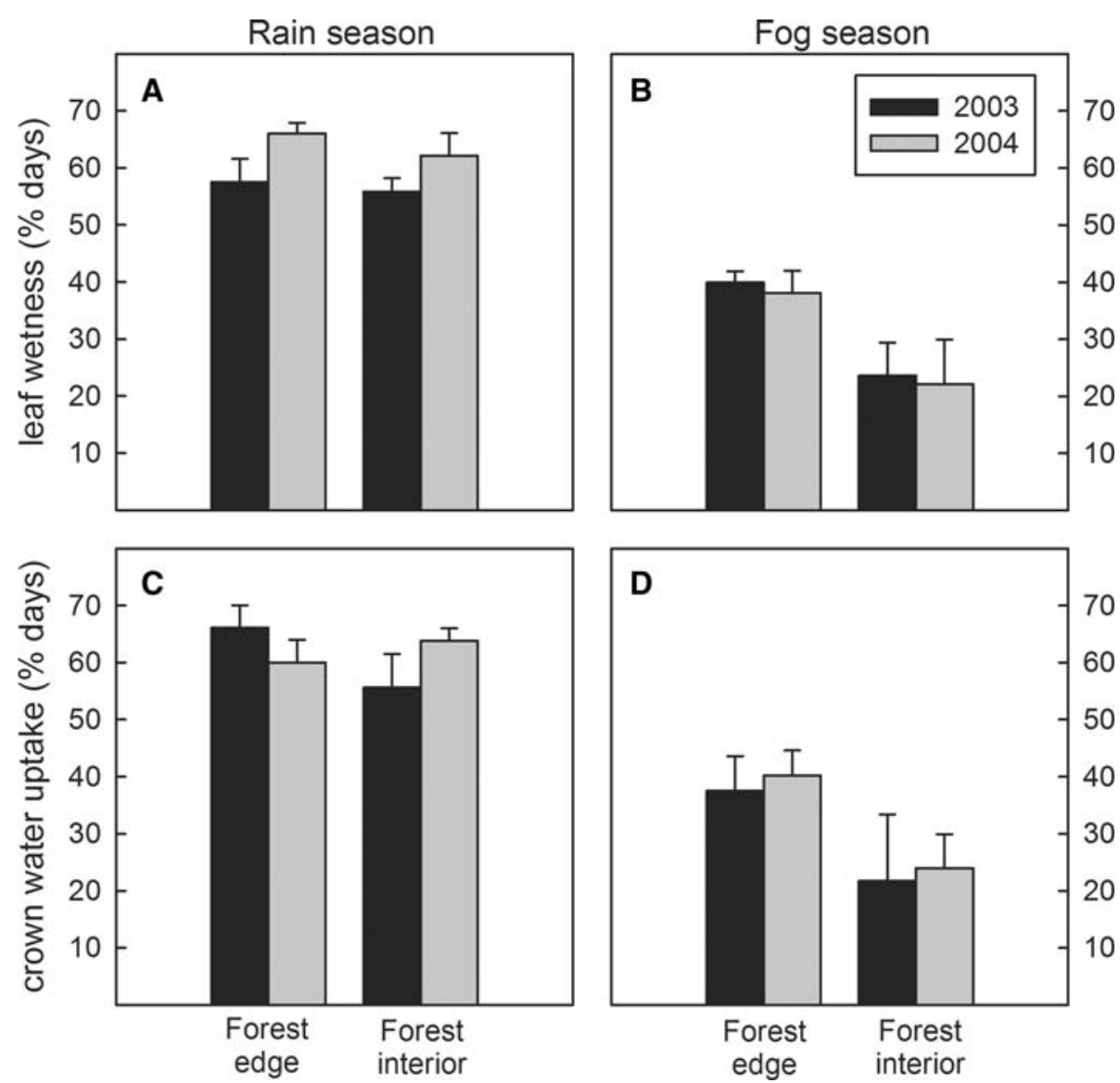

Figure 5. Leaf wetness and tree crown water uptake based on reversals in branch sapflow (after Burgess and Dawson 2004) in mature redwood trees at the edge $(n=3)$ and interior $(n=3)$ forest site positions during the rain (NovemberMay) and fog (May-November) seasons in 2003 (black bars) and 2004 (gray bars). The data are expressed as the percentage of days within that particular season when leaf wetness sensors and sap velocities measured at least $2 \mathrm{~h}$ of water accumulation and reverse flows, respectively. Bars are means with standard errors.

\section{Soil Water}

On average across the entire forest stand, $\mathrm{NO}_{3}^{-}-\mathrm{N}$ was greater than $\mathrm{NH}_{4}^{+}-\mathrm{N}$ in both TL and ZTL (Table 2). Tension lysimeters at the forest edge collected water containing $\mathrm{N}$ in the first weeks of the fog season and again following fog water drip. During the rain season, an average of only $16 \%$ of the $\mathrm{N}$ in ZTL collections was in the form of $\mathrm{NH}_{4}^{+}-\mathrm{N}$ even though one-third of the $\mathrm{N}$ reaching the forest floor was $\mathrm{NH}_{4}^{+}-\mathrm{N}$ (Tables 1, 2 and 3, Figure 4). During the rain season, $\mathrm{NO}_{3}^{-}-\mathrm{N}$ concentrations were generally higher in the interior compared to the edge zones for both TL and ZTL, and $\mathrm{NO}_{3}^{-}-\mathrm{N}$ concentrations in TL water generally exceeded that in ZTL. In contrast, ZTL water contained higher concentrations of $\mathrm{NH}_{4}^{+}-\mathrm{N}$ than TL.

Overall, $\mathrm{N}$ leaching below $70 \mathrm{~cm}$ in the soil occurred primarily in the rain season. One set of ZTL at the leeward end of the forest patch collected water for the first month of the fog season, but all other lysimeters were empty except for the first week of the fog season. Although $\mathrm{N}$ concentrations in ZTL water were low, an average of $82 \mathrm{~cm}$ of water was collected at $70 \mathrm{~cm}$ in the rain season (Table 1). Estimated cumulative leaching of $\mathrm{N}$ from the top $70 \mathrm{~cm}$ of the soil profile suggests that $\mathrm{N}$ leaching in the forest may be greater than annual input via TF (Table 3).

\section{Canopy Wetness, Transpiration, and Litterfall}

Tree canopies remained wetter on average in the rain than in fog season. Xylem pressure potentials were less negative and the duration of canopy wetness, canopy water uptake, and transpiration were all greater during the rain compared with the fog season (Figures 5 and 6). Across the forest during the rain season, there were no differences between edge and interior trees in leaf wetness, canopy uptake, xylem pressure potential, or transpiration (Figures 5 and 6). Additionally, the carbon isotope composition of new leaves produced in the rain season showed no significant difference across the forest $(-25.5$ to $-27 \%$ o $)$, though these values were more negative (meaning less conservative water use) than those measured for leaves produced in the fog season. During the fog season, fog events kept canopies moist on average until 09:00-11:00 and persisted longer at the western edge of the forest than in the forest interior 

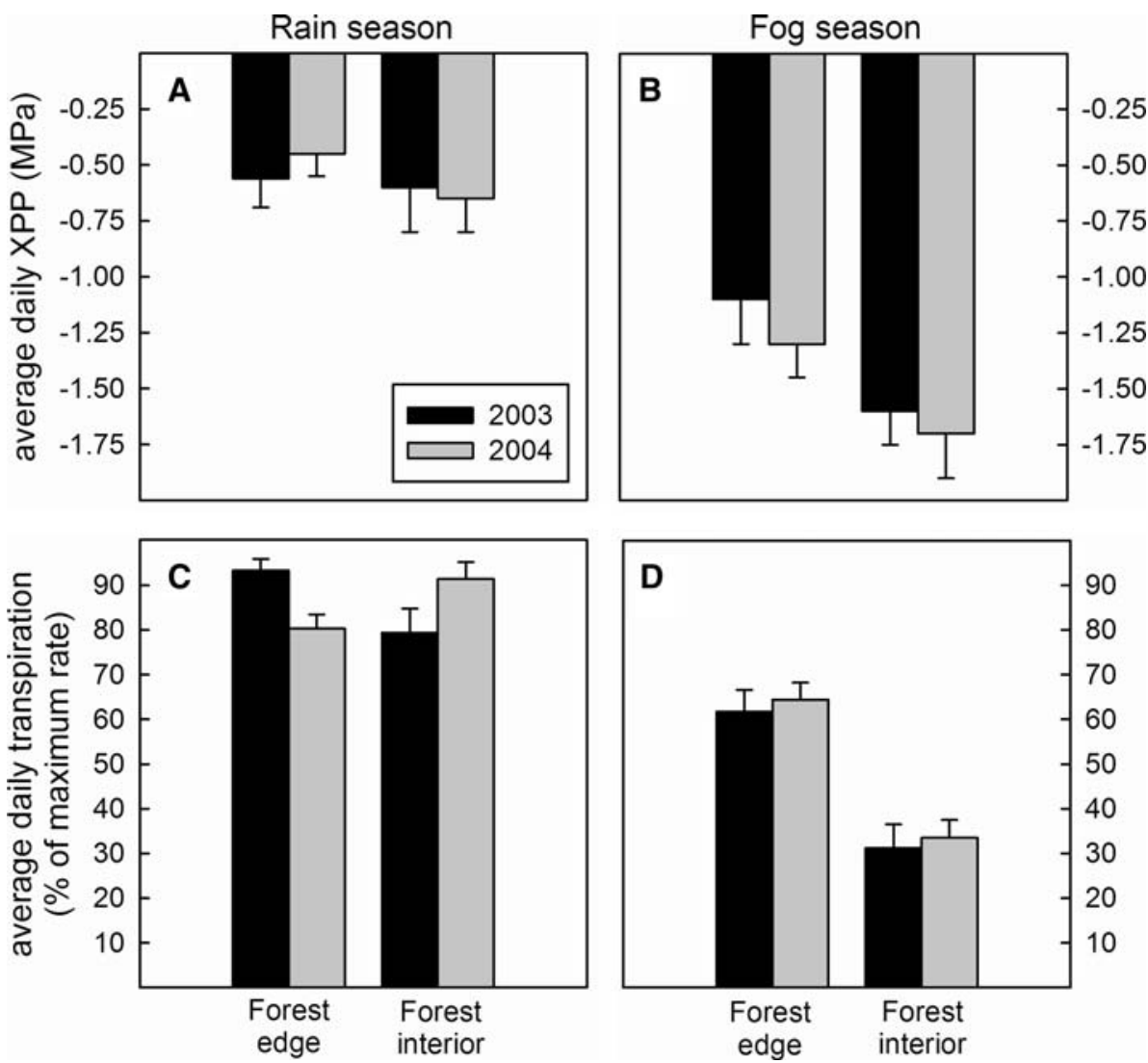

Figure 6. Daily average xylem pressure potential (XPP, MPa) and estimated whole-tree transpiration, expressed as the percentage of the maximum rate measured on mature redwood trees at edge $(n=3)$ and interior $(n=3)$ forest site positions during the rain (NovemberMay) and fog (May-November) seasons in 2003 (black bars) and 2004 (gray bars). The XPP values are based on measurements taken near tree tops (54-63 $\mathrm{m}$ above the ground) near mid-day (12:3014:00) and averaged over the entire season. Bars are means with standard errors.
(Dawson and others, unpublished). Tree crowns wetted by fog impaction often remained wet for an entire day without significant throughfall occurring (interior trees in Figure 5 versus Figure 2). Additionally, when fog events led to sapflow reversals (water uptake through the crown) this often lasted longer in trees at the western forest edge relative to those in the forest interior (Dawson and others, unpublished), and this additional water deposition directly to the tree crown had a clear influence on daily maximal transpiration rates once the fog had burned off and transpiration resumed (Figure 6). The higher water use by forest edge trees was in part driven by the greater total leaf area on edge trees (because of branches extending all the way to the ground), so that edge trees consumed more water annually than interior trees (Figures 3 and 6). However, leaf carbon isotope composition, assessed during the fog season, indicated that edge trees were actually more conservative in their water use compared to interior trees $(-24$ to $-25 \%$ vs. -25 to $-26.5 \%$ for edge and interior, respectively).

Litterfall maxima occurred in September and October but all materials, including leaves and reproductive structures, accumulated in litter baskets throughout the year. Leaves accounted for $86 \%$ of litterfall across all baskets. Total litterfall was generally higher near the windward edge of the forest and decreased linearly with distance from the edge $\left(R^{2}=0.23 P<0.01\right)$.

\section{Discussion}

A three-dimensional perspective is essential for understanding both patterns of water (Nadkarni and Sumera 2004) and nutrient fluxes (Edmonds and others 1991) and ecosystem responses to them within this redwood forest: in the fog season, there are strong horizontal gradients in inputs and spatial variability in tree function that is related to offsets in the timing of daily and seasonal wetting and drying across locations within the forest. In general, patterns in the rain season are less complex spatially in horizontal dimensions than those in the fog season. However, in both seasons ecosystem processing in vertical dimensions was revealed, in part by examining differences in water fluxes, concentrations of $\mathrm{N}$ species, and tree activity.

\section{Rain: A Homogenizing Force}

Differences in water, heat, and $\mathrm{N}$ both throughout the forest and between the forest and the adjacent 
clearing were smaller in the rain than fog season (Tables 1, 2 and 3, Figures 2-4, and Results). Despite the relative homogeneity of rain deposition and TF flux throughout the forest, there was still a small enhancement of $\mathrm{N}$ flux at the western edge of the forest (Table 3, Figure 4), perhaps as a result of more in-canopy $\mathrm{N}$ fixation and/or processing, or higher dry deposition compared to the interior of the forest. This small edge enhancement of $\mathrm{N}$ deposition did not appear to influence plant function with respect to water use; there were minimal differences between trees at edge and interior locations in sapflow, xylem pressure potential, and $\delta^{13} \mathrm{C}$ (Figures 5 and 6 and Results). As $98 \%$ of water and $89 \%$ of $\mathrm{N}$ in TF flux occurred, on average, across the forest in the rain season, this is the season in which atmospheric inputs can most directly benefit plants. In fact, physiological studies show greater plant activity in this season (Burgess and Dawson 2004; Simonin and others, unpublished). Both redwoods and understory plants use rain-derived water (Dawson 1998); rain deposition is clearly vital to the long-term persistence of redwood forest ecosystems over horizontally extensive areas.

\section{Vertical Processing}

Although water and $\mathrm{N}$ fluxes in the rain season were horizontally uniform, the amount of water and form of $\mathrm{N}$ was modified during vertical movement through the forest. First, rain water was taken up by or evaporated from the forest canopy, as others have found for forests of the Pacific Northwest (for example, Nadkarni and Sumera 2004; Figure 2). Water flux to the forest floor is known to be influenced by tree architecture (Dawson 1998; Weathers 1999). Redwood trees have high surface area with leaf area indices (LAI) of 12-16 (Stancioiu and O'Hara 2005; Sillett and Van Pelt 2007). Using Stancioiu and O'Hara's (2005) regressions relating area of sapwood of trees and LAI at this site, Dawson and others (unpublished) estimated LAI to be 14.6 for the forest canopy here. Evaporative loss from the canopy would likely be large for a canopy with this much surface area, and evaporative loss is a primary explanation for greater water deposition outside a forest relative to in it (Weathers and others 1992, 1995). However, our data show reverse sapflow on more than half of the days in the rain season indicating that canopy water uptake is responsible for part of the difference between bulk deposition and throughfall flux (Figure 5). Although it is likely that $\mathrm{N}$ in water taken up by the canopy could be utilized by redwoods, the canopy appears to be a net producer of both $\mathrm{NO}_{3}^{-}-\mathrm{N}$ and $\mathrm{NH}_{4}^{+}-\mathrm{N}$ : TF exceeded atmospheric deposition to the canopy during the rain season (Table 3, Figure 4). This difference could result from dry deposition and/or biological processing (Erisman and others 1997; Weathers and others 2001; De Schrijver and others 2007) and points to the need to understand withincanopy uptake, release, and transformation of $\mathrm{N}$. Furthermore, although wet $\mathrm{N}$ deposition to the canopy was approximately two times greater in the rain than fog season, approximately 10 times more $\mathrm{N}$ came through the canopy during the rain compared to the fog season (Tables 2 and 3). These larger positive net throughfall fluxes in the rain season indicate some combination of more leaching in the canopy, less canopy uptake, and/or more dry deposition of $\mathrm{N}$ in the rain relative to the fog season (Figure 4); we are unable to discern the relative contributions of these processes with this dataset.

Changes in $\mathrm{N}$ concentration between water deposited to the forest floor as TF and collected in lysimeters also showed vertical processing of nutrients. The decrease in $\mathrm{NH}_{4}^{+}-\mathrm{N}$ concentrations between TF and TL suggests rapid uptake by microbes or plants. In contrast, $\mathrm{NO}_{3}^{-}-\mathrm{N}$ concentrations increased between TF and lysimeters in many locations suggesting that nitrification was ongoing during the rain season.

Collections in the ZTL reflect water use in the upper $70 \mathrm{~cm}$ of the soil profile. The abundance of free-flowing water at $70 \mathrm{~cm}$-as evidenced by water lost from the upper soil profile and collected in ZTL-between November and May suggests that water inputs in the rain season were in excess of what was evaporated or immediately usable by plants rooting in the upper $70 \mathrm{~cm}$ of soil. The relative constancy of volumetric water content as measured by the $70 \mathrm{~cm}$ probe at the interior forest site-even during rain events-further suggests that the soil there was saturated for much of the rain season (Figure 3). Soils both on the edge and in the adjacent grassland appear to dry somewhat between rain events, even at $70 \mathrm{~cm}$ depth. Plant water demand at both the forest edge and in the grassland may have influenced soil water content. The hypothesis of greater plant water demand at the forest edge is supported by higher transpiration in edge trees and the slightly smaller leaching losses measured in edge ZTL relative to those in the forest interior.

Although the $\mathrm{N}$ concentration of the solution collected in ZTL was low, the large volume of water exiting the top $70 \mathrm{~cm}$ of the profile makes this a route for substantial $\mathrm{N}$ loss from surficial soil. That losses of $\mathrm{N}$ in soil solution from surficial soil are of the same order of magnitude as TF fluxes parallels 
findings from California rangeland (Lewis and others 2006), and points to leaching as the major avenue of $\mathrm{N}$ loss from surficial soil-although we did not quantify $\mathrm{N}$ gas losses in this study and therefore cannot evaluate the importance of this avenue for loss. As in the rangeland, microbial activity during the dry season creating nutrient availability in excess of plant uptake could produce the large pulse of $\mathrm{N}$ collected in ZTL early in the rain season (data not shown). However, in the redwood forest, the $\mathrm{NO}_{3}^{-}-\mathrm{N}$ concentrations in ZTL are an order of magnitude lower than those in streamwater from the California oak-grassland system (Lewis and others 2006) suggesting that nitrification is a less common process, denitrification is more common, or there is stronger competition for $\mathrm{NO}_{3}^{-}-\mathrm{N}$ within redwoods relative to oakgrassland systems. Because the forest remains cooler and moister than grassland during the summer (Figure 3 and Results) both microbial processing and plant uptake may occur for a larger part of the growing season than is possible in oak woodland or grassland systems. Additionally, the similarity of inputs and losses suggests either that the forest and its soils are no longer aggrading or that recycling of $\mathrm{N}$ occurs from deeper soil layers.

\section{Fog as a Creator of Heterogeneity in Three Dimensions}

\section{Horizontal Variability and Edge Effects}

During the fog season spatial heterogeneity in water and $\mathrm{N}$ was pronounced in both horizontal and vertical dimensions (Tables 1, 2 and 3, Figures 2-6). This pattern contrasts with that of the rain season when there is little horizontal heterogeneity of inputs, and ecosystem processing occurred primarily in the vertical dimension. The horizontal differences in the fog season were a function of a large edge-to-interior gradient in fog water input, a common result of the combination of meteorological phenomena and structural discontinuity at the forest edge (Beier and Gundersen 1989; Weathers and others 2001). Edge effects are pronounced for substances that are horizontally driven, such as gases, particles, and fog droplets (Weathers and others 1995, 2001). Thus, a change in vegetation structure from low-statured vegetation to forests, similar to the change at the windward edge of this forest, has been demonstrated to influence input of water (del-Val and others 2006; Weathers and others 1995, 2000, 2001) and N (Pocewicz and others 2007), tree water use efficiency (Burgess and others 2006), and heat ex- change (Chen and others 1992) in forest patches and trees within those patches. Here, based on calculation of the half-deposition distance (sensu Weathers and others 1995), the functional edge zone extends approximately $30 \mathrm{~m}$ into the forest patch. Thus, the edge zone is where most of the below-canopy effects of fog might be expected in this forest. Beyond this zone, the importance of fog is much greater in the canopy than below it.

Fog drip (TF) reaching the soil may be particularly important for summer plant function. Surficial soils at the forest edge rapidly dried after a fog-drip wetting event (Figure 3), and free-flowing water below $70 \mathrm{~cm}$ did not collect in ZTL after the first few weeks of the fog season, supporting other evidence that vegetation rapidly uses almost all available water in the top of the soil profile (Dawson 1998; Simonin and others unpublished; Limm and others unpublished) in addition to any direct evaporative losses. The availability of fog-drip-derived water for plant use at the forest edge came from water collecting in TLs with only $-50 \mathrm{kPa}$ of pressure on them; soil water potentials greater (less negative) than $-1500 \mathrm{kPa}(-1.5 \mathrm{MPa})$ are considered evidence of plant-available water (Brady and Weil 2002), although redwoods can extract soil water well below these pressures (Burgess and others 2006).

The edge-to-interior gradient in water input was obvious both in soil moisture data and tree physiological responses. The absence of water in TL or response in volumetric soil moisture in the interior of the forest is evidence of lesser water availability in those locations, corroborating the physiological data indicating greater water stress on trees in the interior of the forest-more negative xylem pressure potential and transpiration rates that were a smaller percentage on average of the maximum transpiration rate measured for that location (Figure 6). Trees at the edge had more water available for transpiration and yet the less negative $\delta^{13} \mathrm{C}$ values for redwood needles at the edge suggested more conservative water use in these trees (Figure 3 and Results). Although this may seem contrary to what was found for transpiration using the sapflow data (Figure 6), it is consistent with the fact that edge trees experience more demand for water because of their greater leaf area and edge position (with greater wind velocities and higher evaporative conditions relative to interior trees) where they show daily stomatal closure when demand exceeds soil water supply. This causes higher (less negative) $\delta^{13} \mathrm{C}$ values in the leaves of these same trees (more conservative water use) when assessed at the individual-leaf scale despite overall higher water use when assessed on the whole-plant scale (sapflow). 
Although the forest floor in the forest interior received little fog water, the forest canopy was exposed more consistently to fog even when the fog did not accumulate in sufficient amounts to produce throughfall. Canopy wetness occurred on many more days than throughfall in the interior of the forest (Figure 5 versus Figure 3). This frequent wetness helped relieve water stress relative to dry crowns by reducing transpiration (Kerfoot 1968; Simonin and others, unpublished) and perhaps also through crown water uptake which occurred on $20-50 \%$ of days in the fog season (Figure 5). As such, although there were on average fewer than five fog events per summer capable of substantially increasing the moisture content of the soil, and these increases were seen only at the forest edge (Figure 3), the water intercepted directly by tree crowns and held there still had a significant functional impact. The combination of canopy wetness and uptake without TF and associated soil moisture for root water uptake supports the idea that fog can partially decouple tree crown water status from soil water status and have measurable influences on the functional ecology of redwood forest systems (Burgess and others 2006; Simonin and others unpublished).

Fog $\mathrm{N}$ deposition to the canopy also was greater than that to the soil. Our estimate of atmospheric fog deposition $(0.78 \mathrm{~kg} \mathrm{~N} / \mathrm{ha} / \mathrm{season})$ is approximately half of total bulk deposition to the Sonoma site $(1.88 \mathrm{~kg} \mathrm{~N} / \mathrm{ha} / \mathrm{y})$ and equal to the annual average wet (rain) deposition $(0.77 \mathrm{kgN} / \mathrm{ha} / \mathrm{y} ; 2003-$ 2005) measured at the nearest National Atmospheric Deposition Program site in Hopland CA (CA45, NADP) (Table 3). Thus although rain accounts for $89 \%$ of $\mathrm{N}$ reaching the forest floor across the entire forest, rain deposits only twice as much $\mathrm{N}$ to the canopy as fog because fog is highly chemically concentrated (Table 2). This result is consistent with other studies of fog chemistry (Weathers and others 1986, 1988; Collett and others 1999; Fenn and others 2000; Vitousek 2004).

Our combined results suggest that there was also an edge-to-interior gradient in microbial activity and community composition. Soil water potentials of $-50 \mathrm{kPa}(-0.05 \mathrm{MPa})$, such as those evidenced in edge-but not interior-lysimeters would certainly allow microbial $\mathrm{N}$-transformations including nitrification and N-mineralization (Stark and Firestone 1995). The presence of active microbial processing is also supported by the dramatic decrease in $\mathrm{N}$ concentration between TF and lysimeter water observed at the forest edge after large fog events (Table 2, edge data only). Research in nearby oakgrassland systems suggests that seasonal changes in soil moisture-characteristic of a Mediterranean climate-strongly influence the microbial community (Waldrop and Firestone 2006). On-going work in this redwood forest addresses whether added moisture from fog drip is sufficient to alter the expected seasonal, water-driven changes in soil microbial communities (Bradbury, unpublished) and subsequent nutrient cycling.

The compounded deposition of both water and $\mathrm{N}$ to the western edge of the forest may also be ecologically significant when viewed over longer time scales. For example, we observed greater fine root density and translocation of organic material to greater depth in the soil at the western edge of the forest as evidenced by a $60 \mathrm{~cm}$ A horizon with many fine roots compared to less than $30 \mathrm{~cm}$ for A horizons in other parts of the forest (Ewing and others, unpublished). This contrast in soil development could be a function of differences in water deposition, plant production, understory composition, decomposition, history, or some combination of these factors. As most of these factors may also be related to the higher water and nutrient deposition contributed by fog to the windward edge of the forest, the gradient in fog water inputs may have an important influence on soil characteristics and genesis.

\section{Vertical Processing}

As in the rain season, substantial vertical processing of $\mathrm{N}$ occurred as water passed through the canopy. Overall, our data suggest that there was net leaching of $\mathrm{NH}_{4}^{+}-\mathrm{N}$ from the canopy and uptake of $\mathrm{NO}_{3}^{-}-\mathrm{N}$ during the fog season (Table 3, Figure 4). The difference between $\mathrm{N}$ species delivered to the canopy and $\mathrm{N}$ species reaching the forest floor reveals a somewhat different pattern than that observed in Olympic National Forest (Edmonds and others 1991), but the mechanism is unclear. For example, it is unknown whether the positive NTF of $\mathrm{NH}_{4}^{+}-\mathrm{N}$ results from dry deposition or $\mathrm{N}$-fixation-the latter being possible in warm temperatures and fog wetness in the canopy. Also, it is unclear whether the apparent $\mathrm{NO}_{3}^{-}-\mathrm{N}$ uptake in the canopy is due to microbial processes or direct canopy uptake. Previous work in fog-dominated systems has shown canopy uptake of $\mathrm{N}$ (Clark and others 1998), and these as well as our data emphasize the need to investigate whether direct uptake of $\mathrm{N}$ occurs within tree crowns as well as other mechanisms of canopy influence on $\mathrm{N}$ concentrations.

Processing of $\mathrm{N}$ also clearly occurred in the soil during the times that fog water reached and wet the 
soil sufficiently to allow collection in TL. Concentrations of $\mathrm{NH}_{4}^{+}-\mathrm{N}$ in TL were almost always at or below detection limit during the fog season, even though TF contained substantial amounts of $\mathrm{NH}_{4}^{+}-\mathrm{N}$, suggesting strong demand by microbes and plants in the forest floor (Table 2). Likewise at the forest edge $\mathrm{NO}_{3}^{-}-\mathrm{N}$ concentrations in TL were considerably lower than those in TF, suggesting $\mathrm{NO}_{3}^{-}$use as well (Table 2). However, the few collections of water in $\mathrm{TL}$ in the interior of the forest in the fog season had much greater concentrations of $\mathrm{NO}_{3}^{-}-\mathrm{N}$, suggesting that water available in the forest floor interior led to nitrification in excess of immediate $\mathrm{NO}_{3}^{-}$uptake. This difference between edge and interior sites in vertical processing of $\mathrm{N}$ further underscores the potential importance of fog in ecosystem function and the likelihood that microbial communities and processing differ in relation to fog input.

\section{Fog and Ecosystem Effects}

How are the influences of rain and fog combined in ecosystem structure and function? As noted above, trees at the windward forest edge have greater total leaf area, and litterfall data support a hypothesis of greater forest production at the edge. Litterfall, one integrative measure of overall plant production, shows a spatial pattern that suggests biological averaging of rain and fog influences; litterfall declines linearly from windward edge to interior $\left(R^{2}=0.23, P<0.01\right)$, rather than exponentially as TF does in the fog season (Figure 2), perhaps because of the more horizontally homogeneous contributions in the rain season and the influence of fog throughout all of the forest canopy. Nevertheless, greater litterfall and soil organic content at the windward edge of the forest and the differences in tree function and leaf isotopic signatures at the edge relative to the forest interior suggest that the effect of fog on ecosystem function may be in some way proportional to the amount of fog water deposition and TF flux.

Together these data from rain and fog seasons show profound seasonal differences not only in ecosystem fluxes and processing from atmosphere through soil but also in the degree of coupling among ecosystem compartments within this redwood forest ecosystem. Canopy and soil processing of $\mathrm{N}$ deposition were clear in both seasons, and these transformations-and their differences across seasons-along a vertical transect through the ecosystem highlight the importance of considering multiple dimensions of an ecosystem when quantifying such functions as nutrient cycling. On a horizontal transect through this system, spatial patterns are strongly related to season. During the rain season there is a coupling from atmosphere to soil water as result of vertical fluxes, and heterogeneity in inputs and tree activity are at their minima. The fog season, in contrast, features distinct horizontal heterogeneity in water and nitrogen fluxes to edge versus interior zones of the forest as well as a vertical decoupling of the tree crowns and soils. This decoupling in ecosystem function between edge and interior zones suggests that although fog may be influencing tree function in the forest canopy throughout the entire stand, in the absence of fog drip to the forest floor, other ecosystem processing, such as soil nutrient cycling via microbial activity, belowground respiration, or water uptake by plant leaves in the interior zone would be lower or absent.

\section{ACKNOWLEDGMENTS}

S. Simkin assisted with study design, field set-up, and initial sampling; D. Bradbury helped set up field sites, collected many throughfall and lysimeter samples, and provided constructive feedback on the manuscript; S. Burgess established the sapflow study and helped with interpretation of physiology data; D. Herman and J. Hu contributed to field sampling; S. Mambelli assisted with field sampling, litter sorting, and isotopic analyses. Comments from $\mathrm{M}$. Ball and three anonymous reviewers improved this manuscript. We gratefully acknowledge funding from the A.W. Mellon Foundation to KCW, TED, and MKF.

\section{OPEN ACCESS}

This article is distributed under the terms of the Creative Commons Attribution Noncommercial License which permits any noncommercial use, distribution, and reproduction in any medium, provided the original author(s) and source are credited.

\section{REFERENCES}

Azevedo J, Morgan DL. 1974. Fog precipitation in coastal California forests. Ecology 55:1135-41.

Beier C, Gundersen P. 1989. Atmospheric deposition to the edge of a spruce forest in Denmark. Environ Pollut 60:257-71.

Brady NC, Weil RR. 2002. The nature and properties of soils. Upper Saddle River, NJ: Prentice Hall. 960p.

Burgess SSO, Dawson TE. 2004. The contribution of fog to the water relations of Sequoia sempervirens (D. Don): foliar uptake and prevention of dehydration. Plant Cell Environ 27:1023-34.

Burgess SSO, Dawson TE. 2007. Predicting the limits to tree height using statistical regressions of leaf traits. New Phytol 174:626-36. 
Burgess SSO, Pittermann J, Dawson TE. 2006. Hydraulic efficiency and safety of branch xylem increases with height in Sequoia sempervirens (D. Don) crowns. Plant Cell Environ 29:229-39.

Chen JQ, Franklin JF, Spies TA. 1992. Vegetation responses to edge environments in old-growth Douglas-fir forests. Ecol Appl 2:387-96.

Clark KL, Nadkarni NM, Schaefer D, Gholz HL. 1998. Atmospheric deposition and net retention of ions by the canopy in a tropical montane forest. J Trop Ecol 14:27-45.

Collett JL, Hoag KJ, Sherman DE, Bator A, Richards LW. 1999. Spatial and temporal variations in San Joaquin Valley fog chemistry. Atmos Environ 33:129-40.

Dawson TE. 1998. Fog in the California redwood forest: ecosystem inputs and use by plants. Oecologia 117:476-85.

De Schrijver A, Geudens G, Augusto L, Staelens J, Mertens J, Wuyts K, Gielis L, Verheyen K. 2007. The effect of forest type on throughfall deposition and seepage flux: a review. Oecologia 153:663-74.

del-Val E, Armesto JJ, Barbosa O, Christie DA, Gutierrez AG, Jones CG, Marquet PA, Weathers KC. 2006. Rain forest islands in the Chilean semiarid region: fog-dependency, ecosystem persistence and tree regeneration. Ecosystems 9:598608.

Edmonds RL, Thomas TB, Rhodes JJ. 1991. Canopy and soil modification of precipitation chemistry in a temperate rain forest. Soil Sci Soc Am J 55:1685-93.

Erisman JW, Draaijers G, Duyzer J, Hofschreuder P, Van Leeuwen N, Romer F, Ruijgrok W, Wyers P, Gallagher M. 1997. Particle deposition to forests-summary of results and application. Atmos Environ 31:321-32.

Fenn ME, Poth MA, Schilling SL, Grainger DB. 2000. Throughfall and fog deposition of nitrogen and sulfur at an Nlimited and N-saturated site in the San Bernardino Mountains, southern California. Can J For Res 30:1476-88.

Gower ST, Kucharik CJ, Norman JM. 1999. Direct and indirect estimation of leaf area index, $\mathrm{f}(\mathrm{APAR})$, and net primary production of terrestrial ecosystems. Rem Sens Environ 70:29-51.

Ingraham NL, Matthews RA. 1990. A stable isotopic study of fog: the Point Reyes Peninsula, California, U.S.A. Chem Geol 80:281-90.

Kerfoot O. 1968. Mist precipitation on vegetation. For Abstr 29:8-20.

Lajtha K, Jarrell WM, Johnson DW, Sollins P. 1999. Collection of soil solution. In: Coleman DC, Bledsoe CS, Sollins P, Eds. Standard soil methods for long-term ecological research. New York: Oxford University Press. p 166-82.

Lewis DJ, Singer MJ, Dahlgren RA, Tate KW. 2006. Nitrate and sediment fluxes from a California rangeland watershed. J Environ Qual 35:2202-11.

Lovett GM. 1994. Atmospheric deposition of nutrients and pollutants in North America: an ecological perspective. Ecol Appl 4:629-50.

Nadkarni NM, Sumera MM. 2004. Old growth forest canopy structure and its relation to throughfall interception. For Sci 50:290-8.

Noss R (ed) 2000 The redwood forest: history, ecology, and conservation of the coast redwoods. Washington, DC: Island Press. 339p.
Oberlander GT. 1956. Summer fog precipitation on the San Francisco Peninsula. Ecology 37:851-2.

Odum EP. 1971. Fundamentals of ecology. Philadelphia: Saunders College Publishing. 574p.

Pocewicz A, Vierling LA, Lentile LB, Smith R. 2007. View angle effects on relationships between MISR vegetation indices and leaf area index in a recently burned ponderosa pine forest. Remote Sens Environ 107:322-33.

Rhoades JD, Manteghi NA, Shouse PJ, Alves WJ. 1989. Soil electrical conductivity and soil salinity: new formulations and calibrations. Soil Sci Soc Am J 53:433-9.

Rhoades JD, Raats PAC, Prather RJ. 1976. Effects of liquid-phase electrical conductivity, water content, and surface conductivity on bulk soil electrical conductivity. Soil Sci Soc Am J 40:651-5.

Sillett SC, Van Pelt R. 2007. Trunk reiteration promotes epiphytes and water storage in an old-growth redwood forest canopy. Ecol Monogr 77:335-59.

Stancioiu PT, O'Hara KL. 2005. Sapwood area-leaf area relationships for coast redwood. Can J For Res 35:1250-5.

Stark JM, Firestone MK. 1995. Mechanisms for soil-moisture effects on activity of nitrifying bacteria. Appl Environ Microbiol 61:218-21.

Vitousek P. 2004. Nutrient cycling and limitation: Hawai'i as a model system. Princeton, NJ: Princeton University Press. 248p.

Waldrop MP, Firestone MK. 2006. Seasonal dynamics of microbial community composition and function in oak canopy and open grassland soils. Microb Ecol 52:470-9.

Weathers KC. 1999. The importance of cloud and fog in the maintenance of ecosystems. Trends Ecol Evol 14:214-5.

Weathers KC, Cadenasso ML, Pickett STA. 2001. Forest edges as nutrient and pollutant concentrators: potential synergisms between fragmentation, forest canopies, and the atmosphere. Conserv Biol 15:1506-14.

Weathers KC, Likens GE. 1997. Clouds in southern Chile: an important source of nitrogen to nitrogen-limited ecosystems. Environ Sci Technol 31:210-3.

Weathers KC, Likens GE, Bormann FH, Eaton JS, Bowden WB, Anderson JL, Cass DA, Galloway JN, Keene WC, Kimball KD, Huth P, Smiley D. 1986. A regional acidic cloud/fog water event in the eastern United States. Nature 319(6055):657-8.

Weathers KC, Likens GE, Bormann FH, Bicknell SH, Bormann BT, Daube BC Jr, Eaton JS, Galloway JN, Keene WC, Kimball KD, McDowell WH, Siccama TG, Smiley D, Tarrant RA. 1988. Cloudwater chemistry from ten sites in North America. Environ Sci Technol 22:1018-26.

Weathers KC, Lovett GM, Likens GE. 1992. The influence of forest edge on cloud deposition. In: Schwartz SE, Slinn WGN, Eds. Proceedings of the fifth international conference on precipitation scavenging and resuspension. Richland, WA: Hemisphere Publishing Corporation. p 1415-23.

Weathers KC, Lovett GM, Likens GE. 1995. Cloud deposition to a spruce forest edge. Atmos Environ 29:665-72.

Weathers KC, Lovett GM, Likens GE, Caraco NFM. 2000. Cloudwater inputs of nitrogen to forest ecosystems in southern Chile: forms, fluxes, and sources. Ecosystems 3:590-5. 